Rev. Bras. Saúde Prod. Anim., Salvador, v.16, n.4, p.885-892 out../dez.., 2015 http://www.rbspa.ufba.br

\title{
Metabolic profile of lactating goats fed integral mango meal
}

\section{Perfil metabólico de cabras lactantes alimentadas com farelo de manga integral}

\author{
SILVA, Janaina de Lima ${ }^{1}$; GUIM, Adriana ${ }^{1}$; CARVALHO, Francisco Fernando \\ Ramos de ${ }^{1}$; MATTOS, Carla Wanderley²; GARCIA, Diogo Anastácio ${ }^{3}$; SILVA, \\ Elizabeth Regina Rodrigues da ${ }^{1}$; PEREIRA NETO, José Diógenes ${ }^{1}$; VASCONCELOS, \\ João Luiz de Albuquerque ${ }^{1}$
}

\footnotetext{
${ }^{1}$ Universidade Federal Rural de Pernambuco, Departamento de Zootecnia, Recife, Pernambuco, Brasil. ${ }^{2}$ Instituto Federal de Educação, Ciência e Tecnologia, IF Sertão Pernambucano, Departamento de Zootecnia, Petrolina, Pernambuco, Brasil.

${ }^{3}$ Universidade Estadual Paulista Júlio de Mesquita Filho, Departamento de Zootecnia, Jaboticabal, São Paulo, Brasil.

*Endereço para correspondência: silva_janainalima@yahoo.com.br.
}

\section{SUMMARY}

The work was conducted to evaluate the metabolic profile of lactating goats fed diets containing integral mango meal as a replacement for corn. Four levels of replacement $(0,33,66$ and $100 \%)$ were evaluated in diets with forage:concentrate ratio of 60:40. Eight crossbred multiparous lactating Saanen goats $(48.72 \pm 1.99 \mathrm{~kg}$ of BW) were introduced in the experiment 48 days postpartum and maintained up to 124 days of lactation. It was used a double Latin Square $(4 \times 4)$ experimental design, with four treatments, four periods and four animals per square. There was no effects $(\mathrm{P}>0.05)$ for the integral mango meal level on the intake of DM (1890 g/day), CP (278 g/day) and NDF (959 g/day). However, the intake of NFC and TDN decreased $(\mathrm{P}<0.05) 27.9 \mathrm{~g} /$ day and $0.082 \mathrm{~kg} /$ day, respectively, as the dietary integral mango meal increased. The concentrations of urea, creatinine, gamma glutamyl transferase, aspartate aminotransferase, albumin, total protein, glucose, triglycerides, total cholesterol, and magnesium were not altered $(\mathrm{P}>0.05)$ by replacement levels, with average values of $54.52 \mathrm{mg} / \mathrm{dl}, 0.71 \mathrm{mg} / \mathrm{dl}$, 52.59 UI, 77.37 UI, $4.69 \mathrm{~g} / \mathrm{dl}, 9.32 \mathrm{~g} / \mathrm{dl}, 74.44$ $\mathrm{mg} / \mathrm{dl}, 40.10 \mathrm{mg} / \mathrm{dl}, 39.39 \mathrm{mg} / \mathrm{dl}$, and $11.09 \mathrm{mg} / \mathrm{dl}$, respectively. Considering the metabolic profile, mango meal whole can totally replace corn in diets of dairy goats.

Keywords: cholesterol, fruit wastes, GGT, glucose, triglycerides, urea

\section{RESUMO}

O estudo foi realizado para avaliar o perfil metabólico de cabras lactantes alimentadas com dietas contendo farelo de manga integral em substituição ao milho. Foram avaliados quatro níveis de substituição $(0 ; 33 ; 66$ e 100\%) em dietas com relação volumoso:concentrado de 60:40. Oito cabras mestiças Saanen, multíparas e lactantes $(48.72 \pm 1.99 \mathrm{~kg}$ de peso corporal) foram introduzidas no experimento aos 48 dias pós-parto e mantidas até 124 dias de lactação. Utilizou-se como delineamento experimental dois Quadrados latinos $4 \times 4$, com quatro tratamentos, quatro períodos e quatros animais por quadrado. Não houve efeito $(\mathrm{P}>0,05)$ dos níveis de farelo de manga integral sobre os consumos de matéria seca (1890 g/dia), PB (278 g/dia) e FDN (959 g/dia). Contudo, os consumos de carboidratos não fibrosos e nutrientes digestíveis totais reduziram $(\mathrm{P}<0,05) \quad 27,9 \quad \mathrm{~g} / \mathrm{dia} \quad \mathrm{e} \quad 0,082 \quad \mathrm{~kg} / \mathrm{dia}$ respectivamente, à medida que aumentava o teor farelo de manga integral nas dietas. As concentrações de ureia, creatinina, gama glutamil transferase, aspartato aminotransferase, albumina, proteínas totais, glicose, triglicerídeos, colesterol total e magnésio não foram alteradas pelos níveis de substituição, com valores médios de 54,52 $\mathrm{mg} / \mathrm{dl}, 0,71 \mathrm{mg} / \mathrm{dl}, 52,59 \mathrm{UI}, 77,37 \mathrm{UI}, 4,69 \mathrm{~g} / \mathrm{dl}$, 9,32 g/dl, 74,44 mg/dl, 40,10 mg/dl, 39,39 mg/dl e $11,09 \mathrm{mg} / \mathrm{dl}$, respectivamente. Considerando o perfil metabólico, o farelo de manga pode substituir totalmente o milho em dietas de cabras lactantes.

Palavras-chave: colesterol, GGT, glicose, resíduo de frutas, ureia 
Rev. Bras. Saúde Prod. Anim., Salvador, v.16, n.4, p.885-892 out../dez.., 2015 http://www.rbspa.ufba.br

\section{INTRODUCTION}

By 2050, the requirements for meat and milk will increase by $70 \%$, as the world will have an expected population of more than nine billion people (WADHWA \& BAKSHI, 2013). However, producing the amount of animal protein that will be needed to feed the growing population and to reduce the environmental impact are the main challenges to be faced. Meanwhile, despite the fact that there is much residue available as well as discards from the fruit production in Brazil, these potentially employable byproducts are still only used at a low level. Moreover, there is the aggravating fact that the accumulation of residue in inadequate places and the contamination of water and soil resources lead to a consequent increase in disease vectors for the population, which, therefore, makes it relevant to find sustainable ways to use these residues.

Thus, it is important to highlight that the effects of the use of post-harvest wastes in animal feeding are not well known yet, and it is also important to recognize the impact on the metabolism of lactating animals. This indicates the need for an investigation, and in the context of evaluation, the metabolic profile becomes an adequate tool. The metabolic profile allows us to establish the nutritional status of the animals based on the blood analysis of representative groups using biochemical indexes of energy, protein, and mineral metabolism as well as the functionality of organs such as the liver, which is vital for milk production (PEIXOTO \& OSÓRIO, 2007).

The present work was performed with the objective of assessing the effect on the metabolic profile of different levels of integral mango meal as a replacement for corn in the diets of lactating goats.

\section{MATERIALS AND METHODS}

The study was conducted in the Goat Sector of the Animal Science Department of the Universidade Federal Rural de Pernambuco (UFRPE), Recife, Brazil. The animal handling practices followed the recommendations of the National Council for the Control of Animal Experimentation of Brazil (BRASIL, 2008) under the license number 143/2014 granted by the Institutional Committee of Ethics on Animal Use (CEUA).

Four levels of replacement of corn with integral mango meal $(0,33,66$, and $100 \%)$ on a dry matter basis were utilized. The diets were adjusted to meet the requirements recommended by the NRC (2007) for lactating goats with an average production of $2.0 \mathrm{~kg}$ milk/d and $4.0 \%$ fat while maintaining a roughage:concentrate ratio of 60:40 (Tables 1 and 2). The feed was provided ad libitum as a total mixed ration twice daily at $7 \mathrm{~h} 00$ and $16 \mathrm{~h} 00$ after the milking.

The fruits utilized to produce mango meal were those discarded by the producer market of Petrolina city (Northeast of Brazil) due to nonacceptance by consumers; however, they were still of a good condition to use for animal feeding. The entire fresh fruits (pulp, peel, and seed) were ground in forage machines and dehydrated in the sun for 48 hours after the material was stirred every two hours until it was completely dried. Afterward, the dehydrated material was ground using a $10 \mathrm{~mm}$ screen. 
Rev. Bras. Saúde Prod. Anim., Salvador, v.16, n.4, p.885-892 out../dez.., 2015 http://www.rbspa.ufba.br ISSN 15199940

Table 1. Chemical composition of ingredients used in the diet ( $\mathrm{g} / \mathrm{kg}$ of dry matter)

\begin{tabular}{lcccc}
\hline Nutrients & Integral mango meal & Ground corn & Soybean meal & Tifton hay \\
\hline Dry matter $^{1}$ & 915.10 & 880.9 & 870.4 & 879.0 \\
Organic matter & 961.8 & 982.2 & 935.8 & 927.6 \\
Crude protein & 56.0 & 89.1 & 475.0 & 89.0 \\
Ether extract & 41.2 & 42.0 & 17.0 & 14.6 \\
Neutral detergent fiber & 284.0 & 143.0 & 155.0 & 747.0 \\
Acid detergent fiber & 152.0 & 41.5 & 95.0 & 390.9 \\
Non-fibrous carbohydrates & 592.0 & 710.1 & 315.4 & 116.5 \\
Cellulose & 67.0 & 89.5 & 45.0 & 303.1 \\
Lignin & 65.0 & 12.0 & 15.0 & 53.0 \\
Total phenols & 395.7 & - & - & - \\
Condensed tannins & 30.8 & - & - & - \\
\hline
\end{tabular}

${ }^{\mathrm{I}} \mathrm{g} / \mathrm{kg}$ of natural matter.

Table 2. Ingredients proportion and chemical composition of the experimental diets

\begin{tabular}{|c|c|c|c|c|}
\hline \multirow{2}{*}{ Item } & \multicolumn{4}{|c|}{ Replacement levels of corn by integral mango meal (\%) } \\
\hline & 0 & 33 & 66 & 100 \\
\hline \multicolumn{5}{|l|}{ Ingredients $(\mathrm{g} / \mathrm{kg})$} \\
\hline Tifton hay & 600.0 & 600.0 & 600.0 & 600.0 \\
\hline Integral mango meal & 0 & 100.0 & 200.0 & 300.0 \\
\hline Ground corn & 300.0 & 200.0 & 100.0 & 0 \\
\hline Soybean meal & 70.6 & 69.1 & 67.7 & 66.2 \\
\hline Urea & 9.4 & 10.9 & 12.3 & 13.8 \\
\hline Dicalcium phosphate & 7.0 & 7.0 & 7.0 & 7.0 \\
\hline Mineral mix ${ }^{a}$ & 13.0 & 13.0 & 13.0 & 13.0 \\
\hline \multicolumn{5}{|c|}{ Diet composition (g/kg of DM) } \\
\hline Dry matter $^{b}$ & 882.2 & 885.8 & 889.4 & 892.9 \\
\hline Organic matter & 927.3 & 925.3 & 923.4 & 921.4 \\
\hline Crude protein & 140.2 & 140.4 & 140.4 & 140.6 \\
\hline Ether extract & 22.6 & 22.5 & 22.4 & 22.2 \\
\hline Non-fibrous carbohydrates & 314.9 & 304.10 & 293.2 & 282.5 \\
\hline Neutral detergent fiber & 502.0 & 515.9 & 529.8 & 543.7 \\
\hline Acid detergent fiber & 253.7 & 264.6 & 275.5 & 286.4 \\
\hline Cellulose & 218.8 & 209.6 & 206.5 & 205.0 \\
\hline Lignin & 36.5 & 41.7 & 47.0 & 52.3 \\
\hline Total phenols & - & 39.6 & 79.1 & 118.7 \\
\hline Condensed tannins & - & 3.1 & 6.2 & 9.2 \\
\hline Total digestible nutrients & 639.3 & 623.6 & 611.0 & 600.7 \\
\hline \multicolumn{5}{|c|}{$\begin{array}{l}\text { 'Nutrients/kg of product: Vitamin A - 135.000,00 U.I.; Vitamin D3 - 68.000,00 U.I.; Vitamin E - 450,00 } \\
\text { U.I.; Calcium - 240,00 g; Phosphorus }-71,00 \mathrm{~g} \text {; Potassium - 28,20 g; Sulfur - 20,00 g; Magnesium - } \\
\text { 20,00 g; Copper }-400,00 \mathrm{mg} \text {; Cobalt }-30,00 \mathrm{mg} \text {; Chrome }-10,00 \mathrm{mg} \text {; Iron }-250,00 \mathrm{mg} \text {; Iodine - } \\
\text { 40,00 mg; Manganese }-1.350,00 \mathrm{mg} \text {; Selenium - 15,00 mg; Zinc }-1.700,00 \mathrm{mg} \text {; Fluorine - 710,00 mg. } \\
\text { bg/kg as-fed basis. }\end{array}$} \\
\hline
\end{tabular}

Eight crossbred lactating multiparous Saanen goats with an average body weight of $48.72 \pm 1.99 \mathrm{~kg}$ were utilized; they were introduced to the experiment at 48 days after parturition until 124 days into lactation. The acclimation period to the diets, installations and handling was 38 days, followed by 76 days for the experimental period. The goats were distributed randomly in two simultaneous Latin square $(4 \times 4)$ designs and were housed in individual wood 
pens of $6.25 \mathrm{~m}^{2}$, with a feeder and drinker. Before the beginning of the experiment, the goats were identified, treated for endoparasites, and vaccinated against Clostridium. The shed was kept under permanent artificial lighting during all experimental periods ( 76 days).

The trial lasted 76 days and the five experimental periods lasted 19 days and were divided as follows: 14 days for adaptation to the diets and five days to data and samples collect. During all the experiment, the offering and leftovers of feeds were weighed daily to calculate the voluntary intake and to adjust the offered feed to guarantee $15 \%$ of leftovers. Water was provided ad libitum.

The biochemical doses were performed four hours after the first meal on the last collection day of each period. The aliquots of serum from blood samples were obtained by centrifugation at 2,500 rpm and were stored in Eppendorf at $-20^{\circ} \mathrm{C}$ until performing the analysis. The biochemical metabolites analyzed were: glucose, total cholesterol, triglycerides, proteins (albumin and total protein), enzymes (aspartate aminotransferase AST and gamma-glutamyl transferase GGT), substances related to kidney functions (urea and creatinine) and minerals (calcium, phosphorus, and magnesium). Doles ${ }^{\circledR}$ commercial kits and the colorimetric system in a semiautomatic biochemical analyzer, D250 Doles ${ }^{\circledR}$ were used for biochemical analysis.

Data were submitted for variance and regression analyzes at a 5\% significance level by using the software R (R Core Team, 2013).

\section{RESULTS AND DISCUSSION}

There was no effects $(\mathrm{P}>0.05)$ for the integral mango meal level on the intake of DM (1890 g/day), CP (278 g/day) and NDF (959 g/day) (Table 3). However, the intake of NFC and TDN decreased $(\mathrm{P}<0.05) \quad 27.9 \quad \mathrm{~g} /$ day and $0.082 \mathrm{~kg} /$ day, respectively, as the dietary integral mango meal increased. The lack of effects on DM intake shows that the animals accepted the tested ingredient. Besides, the animals were fed a total mixed ration that minimized the selectivity. Since the diets were isonitrogenous (Table 2) and mango meal did not lead to any effect on DMI, naturally the $\mathrm{CP}$ intake by the goats also was no different.

Table 3. Intake of nutrients (g/day) of goats fed diets containing different replacement levels of corn by integral mango meal

\begin{tabular}{lccccccc}
\hline \multirow{2}{*}{ Item } & \multicolumn{3}{c}{ Replacement levels (\%) } & \multirow{2}{*}{ SEM $^{\mathrm{a}}$} & \multicolumn{2}{c}{$P$-value } \\
\cline { 2 - 5 } & 0 & 33 & 66 & 100 & & $\mathrm{~L}^{\mathrm{b}}$ & $\mathrm{Q}^{\mathrm{c}}$ \\
\hline Dry matter & 1918 & 1915 & 1844 & 1871 & 53.63 & 0.17 & 0.63 \\
Organic matter & 1775 & 1769 & 1701 & 1721 & 49.47 & 0.12 & 0.66 \\
Crude protein & 282 & 281 & 271 & 277 & 7.83 & 0.23 & 0.47 \\
Ether extract & 44.56 & 44.49 & 42.59 & 43.41 & 1.22 & 0.06 & 0.44 \\
Neutral detergent fiber & 934 & 962.1 & 954.3 & 984 & 27.27 & 0.10 & 0.96 \\
Non-fiber carbohydrates & 607 & 581 & 536 & 529 & 17.27 & $<0.001$ & 0.35 \\
Total digestible nutrients (kg/day) & 1.23 & 1.20 & 1.13 & 1.12 & 0.03 & $<0.01$ & 0.60 \\
\hline${ }^{\mathrm{a}} \mathrm{SEM}=$ standard error of the mean; ${ }^{\mathrm{b}} \mathrm{L}=$ linear effect; ${ }^{\mathrm{c}} \mathrm{Q}=$ quadratic effect. & & &
\end{tabular}


Rev. Bras. Saúde Prod. Anim., Salvador, v.16, n.4, p.885-892 out../dez.., 2015 http://www.rbspa.ufba.br

For small ruminants, in the case of dairy goats, the maximum and minimum amounts of fiber in the diet, providing higher intake and production efficiency are not well defined, especially when working with alternative feeds such as fruit wastes. Importantly, the average fiber intake (NDF) registered in this study suggests that goats tolerate the relatively high amount of NDF in the diets, coming to represent approximately $50 \%$ of the DM intake and $1.97 \%$ of body weight (BW), without, however, significantly limit intake.

The average intake of $1.17 \mathrm{~kg} /$ day of TDN is slightly lower of recommendation by the NRC (2007), of $1.43 \mathrm{~kg} /$ day for lactating goats with $50 \mathrm{~kg}$ of $\mathrm{BW}$ and milk production of $2.0 \mathrm{~kg} /$ day. This result can be explained by the reduction of 639.3 to $600.7 \mathrm{~g}$ of $\mathrm{TDN} / \mathrm{kg} \mathrm{DM}$ in the experimental diets (Table 2) and due to the quality of the fiber used in the diet, reducing thereby the supply of energy to the animals. These facts are related to the increase in indigestible fractions, represented by phenolic compounds in the diet (tannin and lignin), compromising the microbial action on the substrate.

The concentrations of urea, creatinine, gamma glutamyl transferase, aspartate aminotransferase, albumin, total protein, glucose, triglycerides, total cholesterol, and magnesium were not altered by replacement levels; with average values of $54.52 \mathrm{mg} / \mathrm{dl}, \quad 0.71 \mathrm{mg} / \mathrm{dl}, 52.59$ UI, $77.37 \mathrm{UI}, 4.69 \mathrm{~g} / \mathrm{dl}, 9.32 \mathrm{~g} / \mathrm{dl}, 74.44 \mathrm{mg} / \mathrm{dl}$, $40.10 \mathrm{mg} / \mathrm{dl}, 39.39 \mathrm{mg} / \mathrm{dl}$, and $11.09 \mathrm{mg} / \mathrm{dl}$, respectively (Table 4).

Table 4. Metabolic profile of goats fed diets containing different replacement levels of corn by integral mango meal

\begin{tabular}{|c|c|c|c|c|c|c|c|c|c|}
\hline \multirow{2}{*}{ Item } & \multicolumn{2}{|c|}{ Reference value $^{\mathrm{s}}$} & \multicolumn{4}{|c|}{ Replacement levels (\%) } & \multirow{2}{*}{$\mathrm{SEM}^{\mathrm{f}}$} & \multicolumn{2}{|c|}{$P$ - value } \\
\hline & Min. ${ }^{b}$ & Max. $^{c}$ & 0 & 33 & 66 & 100 & & $\mathrm{~L}^{\mathrm{g}}$ & $\mathrm{Q}^{\mathrm{h}}$ \\
\hline Urea (mg/dl) & 21.4 & 42.8 & 54.92 & 52.25 & 57.81 & 53.12 & 1.60 & 0.99 & 0.68 \\
\hline Creatinine (mg/dl) & 1.0 & 1.8 & 0.76 & 0.61 & 0.69 & 0.79 & 0.03 & 0.51 & 0.08 \\
\hline GGT (UI) ${ }^{\mathrm{d}}$ & 20.0 & 56.0 & 50.76 & 54.80 & 52.04 & 52.79 & 1.77 & 0.46 & 0.12 \\
\hline $\operatorname{AST}(\mathrm{UI})^{\mathrm{e}}$ & 43.0 & 132.0 & 75.00 & 83.66 & 77.40 & 73.42 & 2.61 & 0.51 & 0.12 \\
\hline Albumin $(\mathrm{g} / \mathrm{dl})$ & 2.7 & 3.9 & 4.59 & 4.57 & 4.53 & 5.10 & 0.09 & 0.06 & 0.09 \\
\hline Total protein $(\mathrm{g} / \mathrm{dl})$ & $6.2^{\mathrm{b}}$ & $7.9^{\mathrm{b}}$ & 9.00 & 9.28 & 9.89 & 9.09 & 0.17 & 0.55 & 0.10 \\
\hline Glucose $(\mathrm{mg} / \mathrm{dl})$ & 50.0 & 75.0 & 76.97 & 73.85 & 73.52 & 73.44 & 1.66 & 0.48 & 0.65 \\
\hline Triglycerides (mg/dl) & 21.4 & 42.8 & 38.95 & 42.95 & 38.09 & 40.40 & 1.58 & 0.96 & 0.72 \\
\hline Total cholesterol (mg/dl) & 80.0 & 130.0 & 41.10 & 43.33 & 42.18 & 30.97 & 2.52 & 0.09 & 0.10 \\
\hline Calcium (mg/dl) & 8.9 & 11.7 & 9.13 & 9.01 & 9.16 & 9.51 & 0.10 & 0.03 & 0.08 \\
\hline Phosphorus (mg/dl) & 4.2 & 9.1 & 9.26 & 8.94 & 8.63 & 8.27 & 0.27 & 0.03 & 0.95 \\
\hline Magnesium (mg/dl) & 2.8 & 3.6 & 11.15 & 10.97 & 11.26 & 10.99 & 0.07 & 0.81 & 0.80 \\
\hline
\end{tabular}

${ }^{\mathrm{a}}$ Kaneko et al. (2008); ${ }^{\mathrm{b}}$ Minimum; ${ }^{\mathrm{c}}$ Maximum; ${ }^{\mathrm{d}}$ GGT - Gamma glutamyl transferase; ${ }^{\mathrm{e}}$ AST - Aspartate aminotransferase; ${ }^{\mathrm{f}} \mathrm{SEM}$ - standard error of mean. ${ }^{\mathrm{g}} \mathrm{L}$ - linear effect; ${ }^{\mathrm{h}} \mathrm{Q}$ - quadratic effect.

The concentrations of urea, albumin, and glucose (Table 4) in goats fed a control diet $(0 \%)$ presented with greater values than those considered reference to goats, as mentioned by Kaneko et al.
(2008). The urea and albumin determination in blood serum shows protein metabolic activity of the animal. The urea is a product of nitrogen metabolism excretion, and the albumin 
is the main plasma protein synthesized in the liver, representing 50 to $65 \%$ of total blood protein (WITTWER, 2000). Despite the increase in urea concentration in the diets (Table 2), the diets were balanced and isonitrogenous, thus was not expected increase in the concentrations of urea and albumin. However, there was a reduction in the energy input from the total digestible nutrients when the corn was replaced by integral mango meal, which was verified in the decrease of TDN intake (Table 3). According to with Wittwer (2000) high values of urea in the blood may occur when a low energy diet is provided, which causes a contrary action in the concentration of rumen ammonia. This is caused by the reduction in microbial protein synthesis, which leads to a consequent increase in urea concentration in the blood.

The levels of glucose in the lactating goats fed 33, 66, and $100 \%$ of integral mango meal as a replacement for corn remained within the normal range for goats (KANEKO et al., 2008). It was expected the reducing of the serum glucose concentrations in the lactating goats, since the NFC content of diets reduced with the inclusion of the integral mango meal. According to Mundim et al. (2007) in goats of second and third lactation typically occur lower serum glucose concentrations, resulting from higher demand of this metabolite by the mammary gland, especially in animals with higher milk production. The crossbred Saanen goats used in this study presented low milk production (ranging from 2.04 to $1.97 \mathrm{~kg} /$ day). Therefore, this can probably explain the lack of effect on serum glucose concentration. In the case of ruminants, glucose is insensitive to variations in energy input associated with the diet, as even its blood concentration is regulated by an efficient hormonal mechanism, with few alterations. Thus, decreases in blood concentration should be associated with a high-energy deficit (ROWLANDS, 1980), which was not the case for this study.

The concentrations of creatinine remained lower (Table 4) compared to reference values (KANEKO et al., 2008). However, Sodré et al. (2007) reported that the amount of formed creatinine is relatively constant for a determined subject and is barely affected by feeding with regards to protein intake.

Except total cholesterol, which maintained its levels below the reference values (KANEKO et al., 2008), the triglycerides presented within the normal range (Table 4). The levels of cholesterol are good indexes of adequate concentrations of lipids in the plasma, as they represent approximately $30 \%$ of the total lipids. As previously mentioned, the average NDF intake (Table 3) suggests that the goats tolerate high amount of fiber in the diet, coming to represent approximately $50 \%$ of the dry matter intake. Probably the higher fiber intake contributed to the reduction in the serum levels of total cholesterol. This result corroborates with Ajila \& Prasada Rao (2013), as ingredients containing fiber and bioactive compounds such as polyphenols and carotenoids are important constituents of fruits that affect the reduction of blood cholesterol.

The concentrations of gamma-glutamyl transferase (GGT) and aspartate aminotransferase (AST) were maintained within the normal range (KANEKO et al., 2008; Table 4). We can infer that the tested diets did not promote damage to the liver of the animals, even though these enzymes work as blood biomarkers for the evaluation of metabolic disturbances and hepatic operations (GONZÁLEZ \& 
SILVA, 2003). This result also justifies the absence of an effect on the albumin concentrations that, according to Rowlands (1980), can be altered by hepatic operations, amino acid availability, and diseases involving mainly gastrointestinal parasites.

The serum levels of the minerals, except magnesium $(\mathrm{Mg})$, were altered by the replacement of corn with integral mango meal (Table 4). There was an increase of $0.12 \mathrm{mg}$ calcium $(\mathrm{Ca})$, and reduction of $0.32 \mathrm{mg}$ phosphorus $(\mathrm{P})$ per $\mathrm{dl}$ of serum for each $1 \%$ level of replacement. However, the levels of $\mathrm{Ca}$ and $\mathrm{P}$ were maintained within the normal range described by Kaneko et al. (2008) and González (2000), except magnesium (Mg) as it was greater (Table 4).

The reduction in the levels of $\mathrm{P}$ were related to an unbalance between $\mathrm{Ca}$ and $P$ in the diet, which was in turn promoted by the addition of integral mango meal and the removal of corn, even though they were formulated with the same inclusion of dicalcium phosphate. The relation between $\mathrm{Ca}$ and $\mathrm{P}$ was maintained closely to $1: 1$ (Table 4). According to Underwood (1981), in livestock diets is recommended $\mathrm{Ca}: \mathrm{P}$ ratio of almost $1: 1$ to $2: 1$. McDowell (1992) reported that this ratio $(1: 1$ to $2: 1$ ) is suggested to be the physiological serum ratio to meet the growth requirements, bone formation and maintaining milk production. However, this unbalances need to be corrected in the diet, since the balance of minerals to lactating goats is important to subsequent lactation.

González (2000) reported that the most common deficiency observed is in phosphorus, and the levels of $\mathrm{Ca}$ are relatively constant. The endocrine system and vitamin $\mathrm{D}$, parathyroid hormone $(\mathrm{PTH})$, and calcitonin are responsible for the adjustment of the current amount of $\mathrm{Ca}$; indicating that there should be a low variation in the level of $\mathrm{Ca}( \pm 17 \%)$ when compared to $\mathrm{P}$ $( \pm 40 \%)$ and $\mathrm{Mg}( \pm 57 \%)$. Only $\mathrm{P}$ and $\mathrm{Mg}$ are good indexes of nutritional status compared to mineral balance. Regarding Mg, according to González (2000), homeostatic control did not exist; thus, its blood concentration reflects the levels of minerals in the diet. After its absorption in the intestine by the active transport system, the factors that could interfere with this event is the $\mathrm{Na}: \mathrm{K}$ ratio, the concentration of $\mathrm{Ca}$ and $\mathrm{P}$, and the amount of energy in the diet.

Therefore, integral mango meal can replace up to $100 \%$ of corn without altering the main indexes of energy and protein metabolism. As a result, making a decision regarding the use of integral mango meal depends on factors related to the product availability and the costs associated with acquiring the mango meal.

\section{ACKNOWLEDGEMENTS}

The National Council for Scientific and Technological Development - CNPq, for funding the research project. And the Council for the Improvement of Higher Education Personnel - CAPES for funding research grant to the doctoral student.

\section{REFERENCES}

AJILA, C.M.; PRASADA RAO, U.J.S. Mango peel dietary fibre: Composition and associated bound phenolics.

Journal of Functional Foods, v.5, p.444-450, 2013. 
Rev. Bras. Saúde Prod. Anim., Salvador, v.16, n.4, p.885-892 out../dez.., 2015 http://www.rbspa.ufba.br ISSN 15199940

BRASIL. Law No. 11.794, of 8/10/2008. Regulates the item VII from $\S 1$ of article 225 of the Federal Constitution, establishing procedures for the scientific use of animals; repeals Law No. 6.638, of 05/08/1979, among other measures.

Available in:

$<$ http://www.planalto.gov.br/ccIVIL_03/ Ato2007-2010/2008/Lei/L11794.htm>.

Accessed: July 2013.

GONZÁLEZ, F.H.D. Indicadores sanguíneos do metabolismo mineral em ruminantes. In: GONZÁLEZ, F.H.D.; BARCELLOS, J.O.; OSPINA, H.; RIBEIRO, L.A.O. (Eds.). Perfil

Metabólico em ruminantes: seu uso em nutrição e doenças nutricionais. Porto Alegre: Universidade Federal do Rio Grande do Sul, 2000.

GONZÁLEZ, F.H.; SILVA, S.C. Introdução à bioquímica clínica veterinária. Porto Alegre: Universidade Federal do Rio Grande do Sul, 2003. 198 p.

KANEKO, J.J.; HARVEY, J.W.; BRUSS, M. Clinical biochemistry of domestic animals. 6.ed. New York: Academic Press, 2008. 896p.

McDOWELL, L.R. Minerals in animal and human nutrition. San Diego:

Academic Press, 1992.

MUNDIM, A.V.; COSTA, A.S.; MUNDIM, S.A.P.; GUIMARÃES, E.C.; ESPINDOLA, F.S. Influência da ordem e estádios da lactação no perfil bioquímico sanguíneo de cabras da raça Saanen.

Arquivo Brasileiro de Medicina Veterinária e Zootecnia, v.59, p.306312, 2007.

NATIONAL RESEARCH COUNCIL NRC. Nutrient requirements of small ruminants: sheep, goats, cervids, and new world camelids. 1.ed. Washington, D.C, 2007.
PEIXOTO, L.A.O.; OSÓRIO, M.T.M. Perfil metabólico proteico e energético na avaliação do desempenho reprodutivo em ruminantes. Revista Brasileira de Agrociência, v.13, n.3, p.299-304, 2007.

R DEVELOPMENT CORE TEAM. R: a language and environment for statistical computing. Vienna: $\mathrm{R}$ Foundation for Statistical Computing, 2013.

ROWLANDS, G.J. Metabolites in the blood of beef and dairy cattle. World Review of Nutrition \& Dietetics, v.35, p.172-235, 1980.

SODRÉ, F.L.; COSTA, J.C.B.; LIMA, J.C.C. Avaliação da função e da lesão renal: um desafio laboratorial. Jornal Brasileiro de Patologia e Medicina Laboratorial, v.43, n.5, p.329-337, 2007.

UNDERWOOD, E.J. The mineral nutrition of livestock. 2.ed. England: Commonwealth Agricultural Bureaux, Slough, 1981. 180p.

WADHWA, M.; BAKSHI, M.P.S. Utilization of fruit and vegetable wastes as livestock feed and as substrates for generation of other value-added products. Rome: FAO Publication, 2013.

WITTWER, R. Diagnóstico dos desequilíbrios metabólicos de energia em rebanhos bovinos. In: GONZÁLEZ, F.H.D.; BARCELLOS, J.O.; OSPINA, H.; RIBEIRO, L.A.O. (Eds.). Perfil Metabólico em ruminantes: seu uso em nutrição e doenças nutricionais. Porto Alegre: Universidade Federal do Rio Grande do Sul, 2000.

Data de recebimento: 19/11/2014

Data de aprovação: 28/10/2015 